\title{
A 'Sound' Policy? The RIAA and The Copyright Act
}

\author{
Note \\ by Chadwick Schnee* \\ Spring 2009

\section{Copyright () University of Pittsburgh School of Law \\ Journal of Technology Law and Policy}

The Recording Industry of America (RIAA) has made headlines ${ }^{1}$ and garnered a fair amount of criticism in recent years, both for the first jury trial against an individual copyright infringer ${ }^{2}$ and for its litigation tactics. ${ }^{3}$ In the midst of the RIAA's aggressive litigation, issues related to proof have come to the forefront, particularly regarding the use of Internet Protocol (IP) addresses ${ }^{4}$ to determine the identity of alleged copyright infringers. $^{5}$ Additionally, the RIAA and other organizations have sought to hold

\footnotetext{
* J.D. from University of Pittsburgh School of Law received May 2009.

${ }^{1}$ See, e.g., Recording Industry Wins Judgment in Piracy Case, N.Y. TIMES, Jan. 13, 2007, at C4; Jeff Leeds, Labels Win Suit Against Song Sharer, N.Y. TIMES, Oct. 5, 2007, at C1; Rachel Aviv, File-Sharing Students Fight Copyright Constraints, N.Y. TIMES, Oct. 10, 2007, at B7; Adrian McCoy, Copy protection for music, confusion for buyers, PITT. POST-GAZETTE, Oct. 18, 2007, at A1.

${ }^{2}$ Virgin Records America, Inc. v. Thomas, No. 06-1497 (D. Minn. Oct. 1, 2007).

${ }^{3}$ See David Kravets, RIAA Fights to Avoid Attorney Fees in Dismissed Piracy Lawsuit, WIRED, Oct. 18, 2007, http://www.wired.com/politics/law/news/2007/10/riaa_fees; Marc Fisher, Download Uproar: Record Industry Goes After Personal Use, WASH. Post, Dec. 30, 2007, at M05.

${ }^{4}$ An IP address is defined as a "32-bit binary number that uniquely and precisely identifies the location of a particular computer on the Internet. Every computer that is directly connected to the Internet must have an IP address. ... Most users who access the Internet by means of dial-up, ISDN, DSL, or cable connections receive a sessionbased [sic], temporary IP address." Credo Reference - IP address, WEBSTER's NEW WORLD ${ }^{\text {TM }}$ COMPUTER DICTIONARY, 2003, http://www.credoreference.com/entry/3484396.

${ }^{5}$ See, e.g., Capitol Records v. Foster, No. 04-1569-W (W.D.Okla. July 13, 2006) (order dismissing case and finding defendant eligible for award of attorneys fees); Ken Fisher, The RIAA, IP addresses, and evidence, ARs TECHNICA, Aug. 3, 2006 http://arstechnica.com/news.ars/post/20060803-7416.html..
} 
individuals owning unsecured wireless routers ${ }^{6}$ liable for any illegal file-sharing that takes place through the individual's router. ${ }^{7}$ The RIAA, in their vigilant defense of copyrighted material, has gone too far and legislative action is needed to provide protection for unwary consumers from the aggressive tactics of the RIAA.

Questions related to the RIAA's faulting of digital piracy in their alleged decline in revenue will be examined in the context of their revenue statements. College students, in particular, have been a focus of the RIAA's litigation strategy, and pending regulations may force universities to play a more prominent role in defending the copyrights of members of the recording industry. Within the context of the first federal jury trial against an individual infringer, issues of actual and statutory damages have come to the forefront. Recent interpretations of the Copyright Act in relation to digital piracy should raise concerns about the law's application in this new technological frontier. In particular, issues regarding proof of copyright violations have been increasingly litigated, especially with the growing use of wireless Internet technology.

\section{RIAA Background}

The RIAA is a trade group formed in $1952^{8}$ that "represents the U.S. recording industry," 9 and whose membership is comprised of various record companies. ${ }^{10}$ The

\footnotetext{
${ }^{6}$ A consumer that is receiving access to the Internet through an Internet Service Provider ("ISP”) may chose to obtain a wireless router so that, for example, a laptop could access the Internet without the need for it to be physically connected to a modem. A wireless router can either be password-protected ("secured") or available without a password ("unsecured"), meaning that anyone could access the Internet through the router. For an informative diagram, see Daniel Bardsley et al, Unsecured Wireless Makers Internet 'Free' for Illegal Users, GuLFNEWS, May 28, 2007, http://archive.gulfnews.com/articles/07/05/24/10127401.html.

${ }^{7}$ See, e.g., Declaration of Francisco Zuleta, Atlantic Recording Corp. v. Zuleta, No. 6-1221 (N.D.Ga. Aug. 8, 2006); see also Mark Ballard, P2P Pinball Lawyers Say Ignorance is No Defence, THE REGISTER, Apr. 17, 2007, available at http://www.theregister.co.uk/2007/04/17/davenport_evidence/.

${ }^{8}$ RIAA Celebrates 50 Years of Gold Records, http://www.riaa.com/newsroom.php (follow "2008" hyperlink, then "Aug" link, then the article title link) (last visited June 13, 2009).

${ }^{9}$ RIAA - Who We Are, http://www.riaa.org/aboutus.php (last visited Oct. 24, 2008).

${ }^{10} I d$.
} 
RIAA's mission "is to foster a business and legal climate that supports and promotes [its] members' creative and financial vitality." 11 The RIAA seeks "to foster a business and legal climate that protects the ability of [its] members - the record companies that create, manufacture and/or distribute some 90 percent of all legitimate sound recordings produced and sold in the United States - to invest in the next generation of music." ${ }^{12}$

As the use of the Internet became widespread in the late 1990s, various companies began to develop software that allowed users to freely and non-discriminately share computer files, including MP3s, through peer-to-peer networking. ${ }^{13}$ In 1999, the RIAA took action through its member companies, filing a lawsuit against file-sharing company Napster, ${ }^{14}$ which resulted in the court ordering the company to temporarily shut down. ${ }^{15}$ Since that time, numerous other similar file-sharing programs have become widely used and have also faced legal action by the RIAA. ${ }^{16}$ But, perhaps due to the relatively simple implementation of peer-to-peer file-sharing ${ }^{17}$ and its widespread popularity, ${ }^{18}$ the RIAA has turned its attention to individuals using peer-to-peer networks to share copyrighted music.

\footnotetext{
${ }^{11} I d$.

${ }^{12}$ RIAA - For Students Doing Reports, http://www.riaa.org/faq.php (last visited Oct. 24, 2008).

${ }^{13}$ Peer-to-peer file sharing is the process by which a user downloads a particular file in the role of a client and subsequently makes "them available to other peers in the role of a server," thereby allowing other users to repeat the process upon initiating a download of the file. RAMESH SUBRAMANIAN \& BRIAN D. Goodman, PeER-To-PeER COMPuting: The EVOlution OF A DisRuPTIVE TECHNOLOGY 9 (2005).

${ }^{14}$ See A\&M Records, Inc. v. Napster, Inc., 239 F.3d 1004 (9th Cir. 2001).

${ }^{15} I d$. at 1027-29.

${ }^{16}$ The RIAA has brought legal action against the following peer-to-peer applications: Grokster (see MGM Studios Inc. v. Grokster, Ltd., 545 U.S. 913, 919 (2005)); Aimster (see In re Aimster Copyright Litigation, 334 F.3d 643 (7th Cir. 2003)); Kazaa (see Metro-Goldwyn-Mayer Studios, Inc. v. Grokster, Ltd., 454 F.Supp.2d 966 (C.D.Cal. 2006)); Usenet.com (see Artista Records v. Usenet.com, No. 07-8822 (S.D.N.Y. Oct. 12, 2007); iMesh (see Motown Record Co., L.P. v. iMesh.com, Inc., 2004 U.S. Dist. LEXIS 3972 (S.D.N.Y. 2004)).

${ }^{17}$ Posting of Ed Felton to Freedom to Tinker, http://freedom-to-tinker.com/blog/felten/p2p-15-lines-code (Dec. 15, 2004, 2:25 EST).

${ }^{18}$ LimeWire Now Found on One-Third of All PCs Worldwide, PRWEB, Dec. 13, 2007, http://pdfserver.emediawire.com/pdfdownload/576418/pr.pdf.
} 
Despite then-Senior Executive Vice President and General Counsel Cary Sherman's ironic statement that "[1]itigation is never our first choice," ${ }^{, 19}$ the RIAA began filing lawsuits against individuals in 2003 under the Digital Millennium Copyright Act (DMCA) ${ }^{20}$ justifying its actions through stating: "We simply cannot allow online piracy to continue destroying the livelihoods of artists, musicians, songwriters, retailers, and everyone in the music industry." ${ }^{21}$ The DMCA allows a person complaining of copyright infringement to obtain a subpoena against an Internet Service Provider (ISP) ${ }^{22}$ in order to identify the user allegedly responsible for the infringement. The ISPs provide the name and address of the registered user of the account, and are afforded liability protection against copyright infringement if, for example, "the transmission of the material was initiated by or at the direction of a person other than the service provider." ${ }^{23}$ In practice, however, most ISPs rotate IP addresses among their users, meaning that the complainant must also provide the time of alleged infringement. ${ }^{24}$

The RIAA blamed piracy for a fourteen percent drop in revenue, although no accompanying information regarding any change in profit was released. ${ }^{25}$ In this initial

\footnotetext{
${ }^{19}$ Press Release, RIAA, Recording Industry Sues Napster for Copyright Infringement (Dec. 7, 1999), available at http://www.riaa.org/newsitem.php (follow "1999" hyperlink, then click the release title above). ${ }^{20} 17$ U.S.C. $\$ 512$ (h) (2006).

${ }^{21}$ Press Release, RIAA, Recording Industry Begins Suing P2P File Sharers Who Illegally Offer Copyrighted Music Online (Sept. 8, 2003), available at http://www.riaa.org/news_room.php (click "2003" hyperlink, click "September" and follow link to this release).

${ }^{22}$ An Internet Service Provider is a "company that provides Internet accounts and connections to individuals and businesses. Most ISPs offer a range of connection options, ranging from dial-up modem connections to high-speed ISDN and ADSL. Also provided are e-mail, Usenet, and Web hosting." Credo Reference - ISP, WEBSTER'S NEW WORLD ${ }^{\text {TM }}$ COMPUTER DICTIONARY (2003), http://www.credoreference.com/entry/3484424.

${ }^{23} 17$ U.S.C. § 512(a) (2006).

${ }^{24}$ Jay Dratler, Cyberlaw: Intellectual Property in the Digital Millennium 6-130, footnote 7.1 (2000).

${ }^{25}$ Press Release, RIAA, Frequently Asked Questions about File Sharing Litigation (Sept. 8, 2003), available at $\mathrm{http}: / / \mathrm{www}$.riaa.org/newsitem.php?id=6822F971-3C75-1823-E095-5FE523CE62FC.
} 
wave of litigation under the DMCA,${ }^{26}$ a twelve-year-old girl living in public housing, ${ }^{27}$ grandparents, a dead person, ${ }^{28}$ a number of college students, and a Yale University professor $^{29}$ were served with lawsuits seeking as much as $\$ 150$ million for copyright violations. ${ }^{30}$ As a result of this "shoot first, ask questions later" strategy - one that the RIAA continues to employ in a modified form today - a myriad of people have been wrongfully sued. A retired teacher, for example, "fortunate to have several lawyers in her family," was sued for downloading rap music using a Windows-based program on her non-compatible Apple Macintosh. ${ }^{31}$

Since that time, the RIAA has evolved its litigation strategy by filing "John Doe" lawsuits against individual IP addresses, without resorting to obtaining subpoenas against ISPs under the DMCA. ${ }^{32}$ Since Fall $2003,{ }^{33}$ the RIAA has filed more than 20,000 lawsuits $^{34}$ - some estimates have gone as high as $30,000^{35}$ - against people allegedly downloading copyrighted music online. These lawsuits have usually resulted in settlements between $\$ 3,000$ and $\$ 11,000$, despite the significantly lower retail cost of such songs. ${ }^{36}$ As Electronic Frontier Foundations points out:

They had little choice - even if an individual has a defense, it is generally

\footnotetext{
26 17 U.S.C. $\$ 512(\mathrm{~h})(2006)$.

${ }^{27}$ Helen Kennedy, C-notes For Brianna, DaILy News (New York), Sept. 11, 2003, at 10.

${ }^{28}$ Dead Woman Sued Over Internet Music, UnITED PrESS InT'L, Feb. 4, 2005.

${ }^{29}$ Music Industry Files Hundreds of Lawsuits Against Internet Song Swapper, OnLINE NewsHour, Sept. 9, 2003, http://www.pbs.org/newshour/media/media_watch/july-dec03/riaalawsuits_09-09-03.html.

30 17 U.S.C. $\$ 512(\mathrm{~h})(2006)$.

${ }^{31}$ John Schwartz, She Says She's No Music Pirate. No Snoop Fan, Either, N.Y. TimeS, Sept. 25, 2003, at C1.

${ }^{32}$ RIAA v. The People: Four Years Later, ELECTRONIC FronTIER FOUNDATION (2007), http://w2.eff.org/IP/P2P/riaa_at_four.pdf.

33 Jonathan Bick, Download Enforcers May Be Singing New Tune, 5 No. 8 Internet L. \& Strategy 1 (Aug. 2007).

${ }^{34}$ Marc Fisher, Download Uproar: Record Industry Goes After Personal Use, WASH. Post, Dec. 30, 2007, at M05, available at http://www.washingtonpost.com/wpdyn/content/article/2007/12/28/AR2007122800693.html?nav=hcmodule.

${ }^{35}$ RIAA v. The People, supra note 32 , at 5.

${ }^{36} \mathrm{Id}$.
} 
more expensive to hire a lawyer to fight than it would be simply to settle. Even ignoring the lawsuit can be more expensive than settling; at least one court has entered a default judgment of $\$ 6,200$ against a defendant who failed to contest the lawsuit. Another court awarded a $\$ 22,500$ judgment against a Chicago woman who attempted to fight the lawsuit against her. ${ }^{37}$

Confronted with the possibility of a costly lawsuit against a plaintiff with comparatively unlimited resources, defendants readily feel coerced into settling, regardless of the accuracy of such accusations.

The oft-complained-of notion that the U.S. sound recording industry has faced a steady decline in revenue since 1999 due to piracy is misleading in a number of ways. The main problem with the revenue calculations is that they are generated using a methodology that fails to take into account the use of the Internet, as they are solely based on "manufacturers' shipments at suggested list prices," 38 an undefined term which suggests an adherence to reporting the shipment of physical devices like CDs, rather than intangible procurement, where music is downloaded instead of shipped. The logic behind one of the RIAA's core justifications is astounding - blaming the Internet for all revenue woes without accounting for any gains through its use. Some statistics involving the Internet that were generated since 2004 demonstrate a rapidly growing number of consumers use the Internet to legally download music. ${ }^{39}$

Additionally, according to the RIAA's own statistics, 1999 was a peak year for the recording industry, reaching over $\$ 14.5$ billion worth of revenue. Between 1997 and 1999, for example, there was a nineteen percent increase in the amount of revenue, a gain

\footnotetext{
${ }^{37} I d$. (internal citations omitted).

${ }^{38}$ See RIAA, 2006 Consumer Profile, available at http://76.74.24.142/E795D602-FA50-3F5A-37309C8A40B98C46.pdf. It appears that some revenue information involving the Internet started being collected in 2004.

${ }^{39}$ According to the RIAA, revenue from the Internet grew from \$183.4 million in 2004 to $\$ 878$ million in 2006, an increase of 378\% in just two years. See RIAA, 2006 Year-End Shipment Statistics, available at http://76.74.24.142/6BC7251F-5E09-5359-8EBD-948C37FB6AE8.pdf.
} 
of over $\$ 2.3$ billion during that period. ${ }^{40}$ Looking at the numbers since 1990 , notably, revenues jumped from over $\$ 7.5$ billion to over $\$ 11.5$ billion in 2006 , an increase of almost fifty-three percent, ${ }^{41}$ even though revenue in 2006 was only $73.3 \%$ of what it was in $1999 .{ }^{42}$ Interestingly, one article states that the RIAA has estimated "that it has lost \$3 billion in sales over the past seven years, in large part from music theft online;" meaning that there is recognition that the declining revenue numbers are not solely attributable to digital piracy. ${ }^{43}$

Even the RIAA has admitted that online piracy is not the sole reason for the decline in revenue since 1999, and has stated that its 2003 shipment numbers "suggests some stabilizing trends in the music industry."44 In early 2002, for example, the RIAA said that "there is no simple explanation for the decrease in sales" for 2001, and then proceeded to blame both $9 / 11$ and online piracy for the decline, citing a survey commissioned by the RIAA for the proposition that online piracy is a "large factor contributing to the decrease in overall shipments."45 Interestingly, the particular survey does not claim any link between digital piracy and ownership of CD-R drives - used for writing various data, including music, movies and text, to CDs - but merely states that ownership of the CD-R drives increased between 1999 and $2001 .^{46}$ The survey also reported that " 23 percent of those music consumers [aged between 12 and 54] surveyed

\footnotetext{
${ }^{40}$ See id.

${ }^{41}$ See RIAA, 1999 Yearend Statistics, available at http://76.74.24.142/01F751EA-7C8C-5D03-E206D26FEB360519.pdf; RIAA, 2006 Consumer Profile, supra note 38.

${ }^{42}$ See RIAA, 2006 Consumer Profile, supra note 38.

${ }^{43}$ Laura Smitherman, Digital Patrol: SafeNet's Record in Tracking Internet Piracy Has Made it Entertainers' Favorite Sleuth, BALTIMORE SUN, Oct. 21, 2007, at 1C (emphasis added).

${ }^{44}$ Press Release, RIAA, RIAA Announces 2003 Year-End Shipment Numbers (Mar. 4, 2004), available at http://www.riaa.com/news_room.php (follow "2004” hyperlink; then follow "March" hyperlink).

${ }^{45}$ Press Release, RIAA, Recording Industry Announces 2001 Year-End Shipments (Feb. 25, 2002), http://www.riaa.com/news_room.php (follow "2002” hyperlink; then follow "February" hyperlink). ${ }^{46} I d$.
} 
said that they did not buy more music in 2001 because they downloaded or copied most of their music for free." ${ }^{47}$ Mere ownership of CD-R drives, which began to be included as standard components in computers as technology improved, however, does not equate with more online piracy. Similarly, the survey data is misleading, as it excludes a large section of the populace - consumers of music above the age of $54,{ }^{48}$ while including computer-savvy children without the available finances or transportation to purchase music in person. Additionally, the survey does not state whether music was downloaded or copied illegally, meaning that the number is falsely inflated to include legal downloading through services like iTunes, as well as legal copying of CDs. Instead of recognizing 1999 as the peak year for the recording industry, the RIAA has decided to pin the blame for declining $\mathrm{CD}$ sales almost entirely on online piracy, without considering a number of other significant factors that may have influenced the decline, such as apathy, ${ }^{49}$ the decline of music videos on MTV ${ }^{50}$ or economic conditions in general.

\footnotetext{
${ }^{47} I d$.

${ }^{48}$ U.S. Census Bureau, Annual Estimates of the Population by Sex and Selected Age Groups for the UNITED STATES: APRIL 1, 2000 TO JULY 1, 2007, http://www.census.gov/popest/national/asrh (follow "Median Age and Age by Sex" drop-down hyperlink; then follow "Excel (21k)" hyperlink). While the Census data reveals that a large segment of the population is over forty-five (rather than the fifty-four), it obviously does not reveal to what extent individuals over either age could be classified as "music consumers." Consequently, the RIAA appears to be relying on the underlying assumption that individuals over fifty-four tend not to download music online, which skews the data in order to generate a more favorable data in the eyes of the RIAA's fight against music piracy.

${ }^{49}$ Ken Fisher, Study: P2P Users Buy More Music; Apathy, Not Piracy, the Problem, ARs TeChnICA, Mar. 20, 2006, http://arstechnica.com/news.ars/post/20060320-6418.html.

${ }^{50}$ Gary Burns, Music Television, Museum of BroadCast Communications, http://www.museum.tv/archives/etv/M/htmlM/musictelevis/musictelevis.htm. On Wednesday, February 27,2008 , for example, only four hours out of a twenty-four hour period of programming was devoted to showing music videos. See On-Air: MTV Schedule, MTV, http://www.mtv.com/onair/schedule/mtv/daily.jhtml (last visited Feb. 27, 2008).
} 
College students have become the primary target of RIAA litigation in $2007 .{ }^{51}$ The RIAA regularly sends out hundreds of letters to universities, demanding that the alleged infringer (identified only by an IP address) either agree to a non-negotiable settlement of around $\$ 3,000^{52}$ or face action seeking at least $\$ 750$ per song. ${ }^{53}$ As one court has pointed out regarding the litigation tactics of the RIAA in a case where the defendants were not represented by counsel: "The concern of this Court is that in these lawsuits, potentially meritorious legal and factual defenses are not being litigated, and instead, the federal judiciary is being used as a hammer by a small group of plaintiffs to pound settlements out of unrepresented defendants." ${ }^{, 54}$ This quasi-extortion tactic not only results in crippling costs to defendants - it reportedly wastes millions of dollars of the recording industry’s money. ${ }^{55}$

\section{Universities}

While universities themselves have yet to be the target of an RIAA action for contributory infringement, many have expressed fear of government action related to their role in facilitating digital piracy through their networks. As Provost of the University of Rochester Charles Phelps, who, incidentally, also chaired a Task Force on Technology for the Joint Committee on Peer-to-Peer File Sharing, made up of representatives from the Recording Industry Association of America, the Motion Picture

\footnotetext{
${ }^{51}$ See Press Release, RIAA, RIAA Pre- Lawsuit Letters Go to 22 Campuses in New Wave of Deterrence Program (Dec. 6, 2007), available at http://www.riaa.org/news_room.php (follow "2007" hyperlink; follow "December" hyperlink).

${ }^{52}$ RIAA v. The People, supra note 32, at 9

${ }^{53}$ See 17 U.S.C. 504(c)(1) (2000); RIAA - The Law, http://www.riaa.org/physicalpiracy.php (follow "The Law" hyperlink).

${ }^{54}$ Decision and Order to Show Cause, Elektra Entertainment Group, Inc. v. O’Brien, No. 06-5289 (C.D.Cal. March 2, 2007), available at http://www.ilrweb.com/viewILRPDF.asp?filename=elektra_obrien_070302Decision (ordering RIAA plaintiffs to show cause why case should not be dismissed as to defendant).

${ }^{55}$ Eric Bangeman, RIAA Anti-P2P Campaign a Real Money Pit, According to Testimony, ARs TECHNICA, Oct. 2, 2007, http://arstechnica.com/news.ars/post/20071002-music-industry-exec-p2p-litigation-is-amoney-pit.html.
} 
Association of America, and other universities, said in 2004:

"If [universities] don't fix this, [the government] will, and you won't like it," Phelps said of [increased pressure from the U.S. House of Representatives Judiciary Committee and the RIAA]. "As long as we make some headway, they won't press action." Phelps warns that if the government were to take direct action against file-sharing at universities, [the University of Rochester] and others could potentially be held liable for illegal use of the network. As a result, "the only thing I can think of would be to sever the Web connection and scrub every student's computer clean, but I just think [that] would be a horrible outcome," Phelps said. "I am gravely concerned about that risk."56

Since that time, however, it appears that the government has decided to take the very action that universities feared - federally funding the fight against digital piracy. ${ }^{57}$ Buried within hundreds of pages of the proposed College Opportunity and Affordability Act of 2007 lies a "quietly inserted"58 section that requires universities to, in addition to making file-sharing policies available to students and employees, "develop a plan for offering alternatives to illegal downloading or peer-to-peer distribution of intellectual property as well as a plan to explore technology-based deterrents to prevent such illegal activity.,, 59

Beyond the troubling notions of institutionalizing a form of censorship of information though initializing "technology-based deterrents" or the specter of cutting off students from financial aid through no fault of their own, the fact is that current “alternatives to illegal downloading" aren't necessarily working. Penn State, the first

\footnotetext{
${ }^{56}$ Chadwick Schnee, UR Signs Deal With Napster, CAMPuS TimES, Feb. 5, 2004, at 1, available at http://media.www.campustimes.org/media/storage/paper371/news/2004/02/05/News/Ur.Signs.Deal.With.N apster-598525.shtml.

${ }^{57}$ College Opportunity and Affordability Act of 2007, H.R. REP. No. 110-500, pt. G, s 494 (2007). See also Larisa Mann, Download a Song... Lose Your College Loan; A Proposed Federal Law Would Punish Universities and Students to Protect Copyrighted Music and Movies, CHI. SUN TIMES, Dec. 9, 2007, at B3.

${ }^{58}$ Alexis Fabbri, House Committee Approves Anti-P2P Requirements on Schools, WASHINGTON INTERNET DAILY, Nov. 16, 2007.

${ }^{59}$ Nate Anderson, Oops: MPAA admits college piracy numbers grossly inflated, ARS TECHNICA, Jan. 22, 2008, http://arstechnica.com/tech-policy/news/2008/01/oops-mpaa-admits-college-piracy-numbers-grosslyinflated.ars.
} 
public university to offer such an alternative to downloading music legally through subscribing to the revived and legal Napster music service, ${ }^{60}$ along with the University of Rochester (UR), the first private university to do so ${ }^{61}$ both ended their agreements with Napster in 2007. Prior to the eventual decision to terminate Napster, UR conducted a number of surveys related to its use between March 15, 2004 and April $2005{ }^{62}$ While the three surveys were voluntary and only accounted for $34 \%$ of the users registered at its peak, the results reveal the difficulties of attracting users to such a service and the lack of protection from RIAA retaliation. ${ }^{63}$

One of the initial hopes for offering Napster was that it would help "protect students from prosecution and encourage legal methods of enjoying music." Unfortunately for students, the goal of reducing DMCA notifications ${ }^{65}$ from the RIAA has only met with limited success; despite the fact that the number of notifications generally dropped in 2005 , the number of notifications rose from around twenty-five in March 2004 (when Napster was launched) to over fifty the following month, as well as in September and October. ${ }^{66}$ Additionally, despite efforts to publicize the Napster service, ${ }^{67}$

\footnotetext{
${ }^{60}$ Bridget Smith, Napster Sharing Coming to Campus, The Daily Collegian, Nov. 7, 2003, available at http://www.collegian.psu.edu/archive/2003/11/11-07-03tdc/11-07-03dnews-07.asp.

${ }^{61}$ Sandra Barbosu, Ruckus to Replace Napster, Cdigix, CAMPUS TIMES, Apr. 19, 2007, available at http://media.www.campustimes.org/media/storage/paper371/news/2007/04/19/News/Ruckus.To.Replace.N apster.Cdigix-2852486.shtml.

${ }^{62}$ LisA Brown, ET AL., UNIVERSITY OF ROCHESTER, TAMING THE P2P CONTROVERSY (2005), http://www.educause.edu/ir/library/pdf/EDU05099.pdf.

${ }^{63} I d$.

${ }^{64}$ See, e.g., Lewis Powell \& Colin Brown, Free Music Deal, CAmPus Times, Feb. 5, 2004 at 6, available at http://media.www.campustimes.org/media/storage/paper371/news/2004/02/05/Opinions/Free-Music.Deal598541.shtml.

${ }^{65} 17$ U.S.C. $\$ 512(\mathrm{~h})(2006)$.

${ }^{66}$ Brown, supra, note 62 . It should be noted that the number of notifications dropped during the summer break.

${ }^{67}$ See, e.g., Chadwick Schnee, UR Signs Deal With Napster, CAmPUS TimES, Feb. 5, 2004 at 1, available at http://media.www.campustimes.org/media/storage/paper371/news/2004/02/05/News/Ur.Signs.Deal.With.N apster-598525.shtml. See generally Cyrus Levesque, RIAA Talk Draws Full House, CAMPUS TimES, Feb. 19, 2004 at 1, available at
} 
most eligible students did not take advantage of the service, as only 1,993 people registered for the service at its peak, representing twenty-five percent of those eligible. ${ }^{68}$ Further, all three surveys demonstrated that over half of the users asked used another music program instead of Napster. ${ }^{69}$ Even though most respondents (seventy-seven percent) "agreed that most students [understood] what copyright infringement is," seven percent reported that they would continue to download musically illegally. ${ }^{70}$ Perhaps the most important note is that when "You Find a Song you like on Napster," only zero to two percent of those surveyed actually bought the song, suggesting that there is extremely little commercial viability of such a service. ${ }^{71}$

\section{Copying without copying: The First RIAA Case Against an Individual to Go to}

\section{Trial}

Despite the thousands of lawsuits filed against alleged individual copyright infringers, the RIAA brought its first lawsuit in front of a federal jury in the fall of 2007. ${ }^{72}$ After RIAA investigator MediaSentry ${ }^{73}$ (now known as SafeNet ${ }^{74}$ ) determined $^{2}$ that a user at a particular IP address was sharing 1,702 music files through the peer-to-

http://media.www.campustimes.org/media/storage/paper371/news/2004/02/19/News/Riaa-

Talk.Draws.Full.House-612408.shtml

${ }^{68}$ Brown, supra, note 62.

${ }^{69} \mathrm{Id}$.

${ }^{70} I d$.

${ }^{71} I d$.

${ }^{72}$ See Fisher, supra, note 34.

${ }^{73}$ MediaSentry has come under fire recently from a number of sources, including Oregon's attorney general, who questioned whether the company violated the state's criminal law requiring investigators to be licensed. (See Adam Liptak, In the Heated Fight Over Music Piracy, a Rare Stand for Privacy, N.Y. TIMES, Dec. 31, 2007, at A11). A former target of an RIAA suit that successfully defended herself filed a lawsuit against MediaSentry, among others, stating that it "has for years conducted illegal, flawed and negligent investigations of many thousands of private United States citizens." Complaint at 3, Andersen v. Atlantic Recording Corp., No. 07-CV-934, 2007 WL 1875516 (D. Or. Jun. 21, 2007). While the complaint has been dismissed, the court has granted leave to amend the complaint. Anderson, 2008 WL 483313. Additionally, a former SafeNet CFO pleaded guilty in October for manipulating the company's stock options program to boost its value. Tricia Bishop, Safenet Judge Shows Pity Former CFO Argo Gets 6Month Term in Options Case, BALTiMORE Sun, Jan. 29, 2008, at 1D.

${ }^{74}$ See Press Release, SafeNet, SafeNet Announces Plans to Acquire MediaSentry, Inc., Jun. 2, 2005 , available at $\mathrm{http} / / / \mathrm{www}$. safenet-inc.com/news/view.asp?news_ID=265. 
peer Kazaa network on February 21, 2005, the RIAA filed a "John Doe" lawsuit, and obtained a subpoena against ISP Charter Communications, who revealed the name of the registered user of the IP address, Jammie Thomas. ${ }^{75}$ Despite the allegation of illegally sharing well over a thousand songs, the RIAA chose to bring their action for sharing (as opposed to possessing infringing material) twenty-six of the songs, noting that the court could " "increase the award of statutory damages to . . \$ \$150,000" per infringement" if it so desired. ${ }^{76}$ The defense noted that:

Ironically, defendant is one of plaintiffs' best customers having bought hundreds of dollars worth of their CD's, yet she has shared the same fate as thousands of other individuals who have been sued by various recording company plaintiffs who follow the motto usually attributed to Soldier of Fortune magazine: 'Kill them all; let God sort them out."77

Despite the Mr. Smith Goes to Washington ${ }^{78}$ style appeal of Thomas' fight against the combined, juggernaut forces of the recording industry, her fight was doomed. While others have been successful in fending off the RIAA by pointing out that the use of an IP address merely identifies the person paying for Internet access, rather than the actual infringer, ${ }^{79}$ circumstantial evidence in the case was admitted that linked the IP address to

\footnotetext{
${ }^{75}$ Plaintiff's Statement of the Case, Virgin Records America, Inc. v. Thomas, No. 6-1497 (D. Minn. July 21, 2006), available at $\mathrm{http}: / /$ docs.justia.com/cases/federal/districtcourts/minnesota/mndce/0:2006cv01497/82850/7/.

${ }^{76}$ See Plaintiff's Statement of the Case, Virgin Records America, Inc. v. Thomas, No. 6-1497 (D. Minn. Sept. 17, 2007), available at http://www.ilrweb.com/viewILRPDF.asp?filename=virgin_thomas_070917PltffsStatementofCase.

${ }^{77}$ Defendant's Statement of the Case, Virgin Records America, Inc. v. Thomas, No. 6-1497 (D. Minn. Sept. 17, 2007), available at http://www.ilrweb.com/viewILRPDF.asp?filename=virgin_thomas_070917DeftsStatementofCase.

${ }^{78}$ Mr. Smith Goes to Washington (Columbia Pictures 1939) (the classic Frank Capra film in which Jimmy Stewart stars as a newcomer, idealist lawmaker standing up for the creation of a national camp site for a Boys Scout-type organization against the overwhelming forces of corrupt politicians).

${ }^{79}$ See, e.g., Amended Counterclaims to Defendant's Answer, Atlantic Recording Corp. v. Anderson, No. 05-933, 2006 WL 393436 (D. Ore. Jan. 27, 2006) (42-year-old disabled single mother awarded attorneys fees after RIAA could not prove she downloaded "ganster rap" at 4:24 a.m.); Judgment for Attorneys Fees, Capitol v. Foster, No. 4-1569 (W.D.Ok. Aug. 16, 2007), available at http://www.ilrweb.com/viewILRPDF.asp?filename=capitol_foster_070816JudgmentAttysFees (defendant awarded $\$ 68,685.23$ in attorneys fees after dismissal); see also Ray Beckerman, Recording Industry vs. The People, http://recordingindustryvspeople.blogspot.com/2006/07/riaa-discontinued-case-in-california.html
} 
Jammie Thomas. Specifically, the username found on Kazaa, "tereastarr," was used by Thomas in a number of other applications, namely her e-mail and instant messaging accounts, as well as her MySpace page. ${ }^{80}$ Thomas successfully appealed her case and was granted a new trial based on a finding that "actual dissemination" was required under the Copyright Act, meaning that a jury instruction given in her previous trial was found to be invalid. ${ }^{81}$

\section{Damages}

Thomas argued on appeal that the court should "test the Constitutionality of the application of the minimum statutory amount in the instant matter, because that number is more than a thousand times the actual damages or harm suffered by plaintiffs," citing a law review article for the proposition. ${ }^{82}$ Under the Copyright Act, a person who has infringed upon a copyright is liable for either "the copyright owner's actual damages and any additional profits" or "statutory damages." ${ }^{, 3}$ As the United States, intervening on the issue of constitutionality issue ${ }^{84}$ pointed out, a copyright holder may choose to recover statutory damages in lieu of actual damages an profits, under § 504(c)(1) of the Copyright Act, ${ }^{85}$ meaning that, despite Thomas' allegation that the recording industry only lost

\footnotetext{
(stating that the RIAA dismissed action against defendant in Virgin v. Marson, No. 5-3201 (C.D.Cal. Jan. $24,2006)$ because there was evidence that multiple users had access to either defendant's Internet connection or computer).

${ }^{80}$ See Eric Bangeman, First RIAA Trial Gets Under Way With Jury Selection, Opening Statements, ARS TECHNICA, (Oct. 2, 2007), http://arstechnica.com/news.ars/post/20071002-first-riaa-trial-gets-under-waywith-jury-selection.html.

${ }^{81}$ Memorandum of Law \& Order, Capitol v. Foster, No. 6-1497 (W.D.Ok. Sept. 24, 2008), available at http://beckermanlegal.com/Lawyer_Copyright_Internet_Law/virgin_thomas_080924Decision.pdf.

${ }^{82}$ Id. at 3 (citing J. Cam Barker, Grossly Excessive Penalties in the Battle Against Illegal File-Sharing: The Troubling Effects of Aggregating Minimum Statutory Damages for Copyright Infringement, 83 TEXAS L. REV. 525 (2004)).

8317 U.S.C. 504(a) (2006).

${ }^{84}$ United States' Memo, In Defense of the Constitutionality of the Statutory Damages Provision of the Copyright Act, Virgin v. Thomas, No. 6-1497 (D.Minn. Dec. 3, 2007), available at http://www.ilrweb.com/viewILRPDF.asp?filename=virgin_thomas_071203USBrief.

8517 U.S.C. 504(c)(1) (2006).
} 
twenty dollars at most from the infringement, ${ }^{86}$ the plaintiffs could still collect the $\$ 220,000$ verdict, since the amount falls between the statutory guideline of $\$ 750$ and $\$ 30,000$ for each instance of infringement, ${ }^{87}$ especially since a court may impose statutory damages "[e]ven for uninjurious and unprofitable invasions of copyright." " 88

The gross disparity between the two amounts reveals that the Copyright Act should be specially tailored to issues involving online file-sharing. Despite the fact that current law allows for the imposition of statutory damages, the United States makes the argument for such damages, stating that statutory damages exist due to the difficulty in assessing such damages, and that, citing the plaintiff's memoranda, "potentially millions" of people infringed the works Thomas made available, which has partly accounted for "lost revenues, layoffs, and a diminished capability to identify and promote new talent." 89 Putting aside the issue of whether users actually downloaded the material "made available" to others, which will be discussed later, it is unsettling that the RIAA can only point to generalities, rather than addressing what proportion of their revenues and alleged financial difficulties are attributable to file-sharing generally, or to the defendant in this case, especially considering that the infringer in this case did not profit from the activity.

At the moment, the RIAA is relentlessly filing notices and lawsuits against individuals in their vigilant quest to protect their copyrights, oftentimes collecting settlements from thousands of alleged infringers who may not have the ability to pay for a legal defense. In this scenario of an organization targeting thousands of people with

\footnotetext{
${ }^{86}$ The amount of twenty dollars was based upon testimony of what CDs "generally cost." See Defendant's Motion for New Trial, Virgin v. Thomas, No. 6-1497 (D.Minn. Oct. 15, 2007), available at http://www.ilrweb.com/viewILRPDFfull.asp?filename=virgin_thomas_071015MotiontoSetAsideVerdict. 87 17 U.S.C. 504(c)(1) (2006).

${ }^{88}$ F. W. Woolworth Co. v. Contemporary Arts, 344 U.S. 228, 233 (1952).

${ }^{89}$ See United States' Memo, supra note 84, at 16.
} 
comparatively little resources, it makes sense that the RIAA should undertake a more exacting burden - namely, the RIAA should make an attempt to give a reasonable calculation of their actual damages on a per song basis, thereby allowing an assessment of damages based on the number of infringing songs. Just as the RIAA has sponsored various studies related to music piracy and has employed MediaSentry to locate IP addresses linked with sharing music files, the RIAA should bear the burden of determining whether there were actual damages and the number of instances of such infringement. Additionally, independent, unbiased studies determining the average number of times a music file is shared with others online would potentially reveal how many individuals choose to illegally download a particular song instead of making a purchase.

Because of this David versus Goliath situation, Congress should amend the Copyright Act in order protect consumers by eliminating the availability of statutory damages with regard to online file-sharing. Since the RIAA shows no signs of reducing the number of complaints it files, there will likely be other suits that make it to jury trials. Under the current system, a successful plaintiff can recover statutory damages of any amount between $\$ 750$ and $\$ 30,000$ for each act of infringement. ${ }^{90}$ The problem, however, is that, in future file-sharing litigation, there will undoubtedly be a wide variance in the amount of statutory damages awarded by a jury on the basis of essentially the exact same facts as those of the Thomas case. As a result, inconsistent jury verdicts will further muddle the determination the essential inquiry - how much is a song worth? In order to alleviate this problem, Congress should take either one of two options: either 1) mandate that statutory damages bear a reasonably relation to actual damages in the

${ }^{90} 17$ U.S.C. § 504(c)(1) (2006). 
case of file-sharing; or 2) set a reasonable amount for damages in the case of file-sharing, based upon inquiries that temper the deterrence aspect of the Copyright Act with the actual harm suffered.

\section{Old law in a new age}

One of the more interesting developments to come out of the case is the confusion over whether simply making a music file available constitutes copyright infringement, or whether an actual transfer of the music must take place. ${ }^{91}$ The issue came up in the course of crafting jury instructions in the Thomas case. The RIAA, citing Perfect $10 \mathrm{v}$. Amazon.com, ${ }^{92}$ argued that making the file available over a peer-to-peer network was enough to violate the Copyright Act. ${ }^{93}$ To establish a claim of copyright infringement, after the copyright holder establishes ownership of the allegedly infringing material's copyright, the plaintiff must demonstrate that the defendant violated "at least one exclusive right granted to copyright holders under 17 U.S.C. $§ 106 . " 94$ In particular relevance to the issue of whether an individual whom possesses music that may be downloaded by others, $\S 106$ provides that the copyright holder has the exclusive right "to distribute copies ... of the copyrighted work."95 Previous cases have applied the Copyright Act to electronic media, pointing out that copies may be distributed electronically. ${ }^{96}$ In Perfect 10 , the court found that merely making copyrighted images "available" does not violate the copyright holder's right of distribution, meaning that Google was not liable for direct infringement because it "did not have a collection of full-

\footnotetext{
${ }^{91}$ Eric Bangeman, Debate Over “Making Available”" Jury Instruction as Capitol v. Thomas Wraps Up (Updated), ARS TECHNICA, Oct. 4, 2007, http://arstechnica.com/news.ars/post/20071004-debate-overmaking-available-jury-instruction-as-capitol-v-thomas-wraps-up.html.

92 Perfect 10, Inc. v. Amazon.Com, Inc., 487 F.3d 701, 717 (9th Cir. 2007).

93 17 U.S.C. $\$ 106$ (2006).

94 A\&M Records, Inc. v. Napster, Inc., 239 F.3d 1004, 1013 (9th Cir. 2001).

9517 U.S.C. $\S 106$ (2000).

96 See, e.g., NY Times v. Tasini, 533 US 483 (2001).
} 
sized images it makes available to the public." ${ }^{.97}$ The court, however, noted that even though Google was not liable for indexing the image files, Napster users did engage in copyright infringement "when they used the Napster software to make their collections available to all other Napster users. ${ }^{998}$

Despite the fact that a claim of copyright infringement relying on the distribution right ordinarily requires actual distribution, ${ }^{99}$ courts appear to have moved away from this idea with respect to file-sharing, seemingly requiring two separate, but related, components to determine liability: 1) Actual possession of copyrighted material, and 2) Capability of copyrighted material being transmitted to others. ${ }^{100}$ Using this reasoning, companies allegedly facilitating copyright infringement, such as Napster, escape direct liability for copyright infringement, ${ }^{101}$ while users of peer-to-peer services, both the ones uploading and downloading material, face the prospect of defending themselves in court. $^{102}$

The reasoning behind this, however, is flawed due to a key difference between cases of file-sharing and the seminal case related to the issue of making a copyrighted work available. ${ }^{103}$ In Hotaling v. Church of Jesus Christ of Latter-Day Saints, the Fourth Circuit used this reasoning to hold the Mormon Church liable for copyright infringement after it reproduced and distributed copies of research materials to its various libraries nationwide for the use of patrons. ${ }^{104}$ While courts have cited this case for the notion that

\footnotetext{
${ }^{97}$ Perfect 10, 487 F.3d at 719.

${ }^{98}$ Id. (citing Napster, 239 F.3d at 1011-14).

${ }^{99}$ See, e.g., Perfect 10, 508 F.3d 1146, 1162 (9th Cir. 2007).

${ }^{100}$ See, e.g., Arista Records LLC v. Greubel, 453 F.Supp.2d 961 (N.D. Tex 2006).

101 See A\&M Records, Inc. v. Napster, Inc., 239 F.3d 1004 (9th Cir. 2001) (holding that users directly infringed upon copyrights, while Napster was liable for "contributory copyright infringement").

102 See id.

${ }^{103}$ Hotaling v. Church of Jesus Christ of Latter-Day Saints, 118 F.3d 199 ( $4^{\text {th }}$ Cir. 1997).

${ }^{104}$ Id. at 203.
} 
merely making the copyrighted materials available to patrons is enough to hold a defendant liable, the overlooked key element is that the church infringed on the copyright when it made copies of the materials and sent them to various branch libraries. ${ }^{105}$ Additionally, the facts also revealed that patrons of the library had actually accessed the infringing material, as one patron reportedly left a photocopy of the work in the library. ${ }^{106}$ While the church potentially faced liability for the original copying and distributing the works, the three-year statute of limitations had run on those claims. ${ }^{107}$ While the church was found liable for making the copyrighted works available, the problem is that this case is cited for the proposition that merely making a copyrighted work available can constitute infringement. ${ }^{108}$ This notion ignores the facts of the case, as actual use of the material occurred by at least one patron, ${ }^{109}$ meaning that the church was liable because it made the work available, indexed the material in its catalog, had physical possession, and there was evidence that patrons accessed the materials. This last fact has been left out in the discussion of whether making copyrighted material constitutes infringement, and should be addressed by the courts in order to require a plaintiff to produce evidence that users actually accessed the copyrighted material. ${ }^{110}$

Applying the faulty reasoning of Hotaling to the Thomas case, the court adopted

\footnotetext{
${ }^{105}$ Id. at 201-202. The statute of limitations, however, barred action against the church based on its copying the materials and distributing them to its branch libraries.

${ }^{106} \mathrm{Id}$. at 202. The act of photocopying the material may have constituted infringement itself.

${ }^{107} I d$.

${ }^{108}$ See, e.g., Arista Records LLC v. Greubel, 453 F.Supp.2d 961, 969 (N.D.Tex. 2006). But see In re Napster, Inc. Copyright Litigation, 377 F.Supp.2d 796, 803 (N.D. Cal. 2005) ("In any event, to the extent that Hotaling suggests that a mere offer to distribute a copyrighted work gives rise to liability under section $106(3)$, that view is contrary to the weight of ... authorities.")

${ }^{109}$ One person made a "paper copy" of the material. 118 F.3d at 202.

${ }^{110}$ In a hypothetical scenario where such a rule was adopted, the plaintiff would have to demonstrate that actual distribution occurred by party not authorized to copy the material, meaning that, in the context of RIAA litigation, proof that a user other than MediaSentry downloaded the material would be required, as MediaSentry would be considered an authorized user of the material, unable to infringe upon the copyrights.
} 
the RIAA's version of copyright infringement: "The act of making copyrighted sound recordings available for electronic distribution on a peer-to-peer network, without license from the copyright owners, violates the copyright owners' exclusive right of distribution, regardless of whether actual distribution has been shown."111 Not all courts, however, have ruled that making song recordings available constitutes copyright infringement.

In $U M G v$. Lindor, for example, the court, in determining whether the plaintiff was precluded from alleging that additional songs other than those stated in the original complaint had been illegally downloaded, found that: "At trial, plaintiffs will have the burden of proving by a preponderance of the evidence that defendant did indeed infringe plaintiff's copyrights by convincing the fact-finder, based on the evidence plaintiffs have gathered, that defendant actually shared sound files belonging to plaintiffs." Importantly, the court in $U M G$ noted that, according to testimony from MediaSentry President Gary Millin in another case, ${ }^{113}$ so-called "dummy files," "fake files," and corrupt files exist on peer to peer file-sharing networks that are indistinguishable from an actual music file until the file is played,${ }^{114}$ meaning that a file may appear to be a copyrighted work when it is found on a peer-to-peer network, though it is not. As a result of the presence of these "fake" files, it is impossible to determine whether a file is actually a music file - and consequently whether it infringes on a copyright - without actually downloading (or, in other words, actual distribution of) the particular file.

Because it is impossible to determine the nature of a music file until it is actually downloaded and played, courts should rule that a plaintiff must demonstrate actual

\footnotetext{
${ }^{111}$ Jury Instruction 15, Virgin v. Thomas, No. 6-1497 (D. Minn. Oct. 15, 2007), available at http://blog.wired.com/27bstroke6/files/jury_instructions.pdf (emphasis added).

${ }_{112}$ Report and Recommendations, UMG Recordings, Inc. v. Lindor, No. 5-1095 (E.D.N.Y. Dec. 12, 2006).

${ }^{113}$ BMG Canada Inc. v. Doe, [2004] F.C. 488 (Can.).

${ }^{114}$ Report and Recommendations, supra note 112.
} 
distribution of an allegedly-infringing file and verify that the file does in fact infringe on a copyright in order to make out a case of copyright infringement. Despite the relative novelty of various Internet-based technologies, courts, in attempting to apply aging law to new concepts, should not overreach in order to spawn judicial rulings that, if applied outside the medium, would make little or no sense. Direct liability should not turn on speculating whether it is possible that one could be able to illegally copy legally purchased material, rather than finding actual distribution.

\section{Unsecured Wireless Routers: Valid defense against RIAA file-sharing?}

As various recording companies assert on online settlement web pages, ${ }^{115}$ owning a wireless Internet connection does not automatically ensure that an individual cannot be identified by the RIAA. ${ }^{116}$ This statement makes sense, as circumstantial evidence such as usernames and other login IDs may suggest that the same person was involved in allegedly infringing a copyrighted work, as seen in the Thomas case. ${ }^{117}$ One "prelitigation" letter appears to insinuate, however, that a person may still be liable for copyright infringement for merely being the owner of an unsecured wireless connection without participating in any infringing activities:

Please note that it is possible that your $\mathrm{IP}$ address may have been used by a third party if you have an unsecured wireless connection or your computer security has been compromised, or if other people or children have access to the computer connected to the internet service provided by your ISP. Accordingly, although your computer may not have been used to carry out the action alleged, your internet connection may have been used. The security of your computer and internet connection is your responsibility and you need to ensure that both are protected at all times with the most

115 See, e.g., P2P Lawsuits, http://www.p2plawsuits.com (last visited Feb. 20, 2008).

${ }^{116} \mathrm{Id}$.

${ }^{117}$ See, e.g., Opening Statement of Richard L. Gabriel (plaintiff's attorney), Virgin Records Am., v. Thomas, No. 06-1497, at 84 (D. Minn. Oct. 2, 2007), available at http://beckermanlegal.com/pdf/?file=/Lawyer_Copyright_Internet_Law/virgin_thomas_071002Transcript1278.pdf (while no wireless Internet connection was involved in this case, other circumstantial evidence, such as her MySpace page and instant messenger ID linked her to her Kazah username). 
up to date anti-virus and firewall software, and ensure that any wireless router is properly encrypted, in order to be certain that your computer is not being used for unlawful purposes and without your knowledge or consent. $^{118}$

Despite this insinuated liability for an owner of an unsecured wireless Internet connection, it is far from likely that the RIAA will be successful in any such suit, as recent cases have demonstrated. ${ }^{119}$ In fact, it is more likely that defendants will be able to use the presence of an unsecured wireless router as either an affirmative defense or in order to raise doubts as to whether the particular defendants infringed upon the copyright.

Unfortunately, since most cases either settle or are dismissed without listing any specific reasons, there is little information related to whether having an unsecured wireless connection is persuasive. In Virgin v. Marson, for example, a cheerleading instructor targeted by the RIAA had the suit dismissed upon stipulation of the parties after disputing the claim that she had infringed anyone's copyrights. ${ }^{120}$ Specifically, Marson stated that her home was regularly open to "over 100 teenage girls [belonging] to the Desert Mavericks cheerleading team"121 that could have used her computer and that she maintained a wireless network that any nearby person could have used to engage in copyright infringement. ${ }^{122}$ While this case does suggest that there may be certain situations where factual circumstances can outweigh the identification of an IP address,

\footnotetext{
${ }^{118}$ Arikia Millikan, Does Unsecured Wireless Make You a Target?, THE Michigan Daily, May 23, 2007, http://thewire.blogs.michigandaily.com/2007/05/23/271/.

${ }^{119}$ See, e.g., Virgin v. Marson, No. 5-3201 (W.D.Ca. Apr. 29, 2005), available at http://www.ilrweb.com/viewILRPDF.asp?filename=virgin_marson_stiporder; Capitol Records v. Foster, No. Civ. 04-1569-W, 2007 WL 1028532 (W.D. Okla. Feb. 6, 2007) (awarding attorneys fees to defendant after plaintiff's unsuccessful attempt to hold defendant liable for activity of other family members using her Internet account).

${ }^{120}$ See Joint Stipulation of Dismissal Without Prejudice, Virgin v. Marson, No. 5-3201 (W.D.Ca. Apr. 29, 2005), available at http://www.ilrweb.com/viewILRPDF.asp?filename=virgin_marson_stiporder; See also, OUT-LAW.COM, Woman forces US record industry to drop file-sharing case, http://www.outlaw.com/default.aspx?page=7165 (last visited Apr. 15, 2009).

${ }^{121}$ David Herman, Music Firms Worry Family, THE PrESS EnTERPRISE (Riverside, CA), Aug. 18, 2006, at B1.

${ }^{122}$ Susan Butler, Legal Matters: The Price for a Song, BiLlboARD, Oct, 7, 2006.
} 
the fact that the defendant owned a wireless router may have been incidental, as she could severely undermine the plaintiff's case against her, by demonstrating that others actually used her computer. Additionally, while the case was dismissed against her, the RIAA decided to file a suit against her daughter, as, according to an unnamed source quoted by Billboard, "“a number of witnesses' identified Marson's daughter as the file-sharer.,"123

In another case, after the RIAA had discovered the owner of the IP address, it was possible to avoid liability for copyright infringement by claiming that the RIAA "sued the wrong person." 124 In Capitol Records v. Foster, the defendant was the registered account holder for the particular IP address, but denied any knowledge of downloading material from the Internet, claiming instead that her husband, whom she had separated from, may have been the person who had allegedly shared copyrighted music. ${ }^{125}$ The RIAA dismissed their claim against Foster, but she refused to dismiss her counterclaims seeking attorney fees, due to her considerable legal expenses. ${ }^{126}$ In the end, Foster recovered over $\$ 61,000$ in attorney’s fees. ${ }^{127}$

Based on these two cases, it appears possible to use the existence of a wireless router as a persuasive defense under the right factual circumstances. Since the mere identification of an IP address cannot positively link a particular person with alleged infringement, ${ }^{128}$ a plaintiff claiming copyright infringement needs to offer additional circumstantial evidence to be successful. While other circumstantial evidence can help

${ }^{123} I d$.

${ }^{124}$ Defendant's Amended Answer and Counterclaim Capitol v. Foster, No. 4-1569, (W.D.Okla. Apr. 4, 2005), 2005 WL 5340288.

${ }^{125} \mathrm{Id}$.

${ }^{126}$ Capitol v. Foster, No. 4-1569, 2007 WL 1223826, at *1 (W.D.Okla. Feb. 6, 2007) (awarding defendant reasonable attorneys fees).

${ }^{127}$ Capitol v. Foster, No. 4-1569, Order and Decision Awarding Defendant Attorneys Fees, 12, (W.D.Okla. July 16, 2007), http://www.ilrweb.com/viewILRPDF.asp?filename=capitol_foster_070716OrderAwardAttysFees.

${ }^{128}$ Capitol v. Foster, No. 4-1569, 2007 WL 1223826, at*1 (W.D.OKkla. July 16, 2007). 
establish the identity of an alleged infringer, ${ }^{129}$ the existence of an unsecured wireless Internet connection can suggest that someone other than the registered account holder allegedly infringed a copyright, especially if there is evidence that other people actually used the Internet connection. ${ }^{130}$

\section{Conclusion}

While copyrights are critically important to the incentive to create new creative works, many people disagree about the proper balance of intellectual property rights in the peer-to-peer context. Due to the unique nature of litigation surrounding peer-to-peer file-sharing, protection should be afforded to the individuals targeted, rightly or wrongly, by aggressive plaintiffs. As organizations like the RIAA continue to seek the identities of thousands of alleged copyright infringers, a number of universities are fighting back, refusing to accept the RIAA's attempt to link IP addresses to real people. ${ }^{131}$ One law school has offered a legal aid clinic in order to defend college students targeted by the RIAA. ${ }^{132}$ Thousands of individuals have, justly or unjustly, been subjected to the strongarm litigation tactics of the RIAA, having to choose between mounting a costly legal defense against a plaintiff with comparatively unlimited resources or settling the case, without any assurance that member recording agencies will not bring any future legal action against them. Congressional action is desperately needed to amend the Copyright Act to provide for, at a bare minimum, proof of actual damages for online file-sharing. Courts need to reevaluate their precedent concerning the "making available" line of cases

\footnotetext{
${ }^{129}$ See, e.g., Virgin v. Marson, No. 5-3201 (W.D.Ca. Apr. 29, 2005).

${ }^{130}$ See id. (dismissing case where evidence existed that multiple other people used her computer).

${ }^{131}$ Nate Anderson, Another School Says "No" to RIAA Prelitigation Letters, ARS TECHNICA, Jan. 2, 2008, http://arstechnica.com/news.ars/post/20080102-another-school-says-no-to-riaa-prelitigation-letters.html.

${ }_{132}$ Trevor Maxwell, Third-year Law Students Take on Recording Industry, PORTLAND PRESS HeRALD, Jan. 7, 2008, at A1.
} 
in order to require actual use of infringing material, thereby bringing the reasoning more in line with reality. Additionally, in cases where an individual file-sharer has been wrongfully accused, attorney's fees should automatically be awarded to the prevailing party as a deterrence against baseless accusations. 